other known body. Herr Eder regards the photo-chemical decomposition of silver bronide as the result of partial reduction with loss of bromine.

\section{THE GERMAN ASSOCIATION}

THE fifty-fourth meeting of the Association of German Naturalists and Physicians was held at Salzburg on Sep. tember 18-24. The number of Members and Associates in attendance was 760 . There were also present Foreign Members from Switzerland, the Netherlands, Russia, 'Denmark, and Japan. The first general meeting, on Sunday, September $\mathbf{x} 8$, was opened by the First Secretary, Dr. Günthnet (Salzburg), who in his hearty ađdre ss of welcome mentioned the fact that Salzburg was the last retirement of the celebrated physician and naturalist, Theophrastus Paracelsus. After short addresses given by the Governor and Burgomaster, Prof. Pettenkofer (Munich) read a paper "On the Soil and its Connection with the Health of Man." He pointed out that it was previou ly believed that the state of the air and water exeris an important influence upon the origin and propagation of epidemics, but this view could not be proved by experiments recently made. The contamination of air and water is caused by prolucts of decomposition of bodies putrefying on or in the soil. The progress of epidemic diseases, especially of cholera, is influenced mainly by the soil. The immunity of special localities against cholera is shown by the example of Lyons, which, notwithstanding communication with infected places, remained free from cholera, though filtered Rhone water was used there. Versailles and Salzburg also were exempt from this disease. It is now ge $3 e-$ rally assumed that cholera is due to the action of schizomycetes, which develop at localities where the soil is impregnated with decomposing organic bodies. The contamination is drawn up by diffusion through the porous so:1 into the interior of houses, where it bec imes dangerous to the health of man.

On Monday the work of the sections was c mmenced. There were twenty-tbree sections, eleven of them medical. On Tuesday an excursion was made to Reichenhall (Bavaria), with its saltmines, where the Congress was addressed by Graf Pestallozza. On Wednesday the second general meeting was held. Prof. Weismann (Freiburg-im-Breisgau) read a paper on the duration of life. After enumerating many examples of longer and shorter duration of life among animals, he pointed out that size, constitution, temper, sex, and growth are not critical for the duration of life. In general the duration of life of an individual represents the minimum of time necessary to insure the existence of the species; it is governed by adaptation and heredity. The death caused by wasting and consumption of the cells, of which the (animal) body is composed, is the result of adaptation. The capacity of unlimited life has been lost, since it has become useless. There is no death at the division of lower animals (Amœba). In higher animals the propagating cells are separated from the somatic cells; only the former preserve unlimited productiveness. The limitation of individuals in time and in space is based on the same principle. At the same meetin $x$ Prof. Meyners (Vienna) gave an address on the laws which govern human thoughts and actions. In the conclusion of his very interesting discourse, in which he mainly dealt with feelings, sensations, and the experiments of Munk and Goltz, he expressed the opinion that the phenomena of bodies do not disclose to us their essence, and that there is only a phenomenon of freedom of will. Eisenach (Thuringia) was chosen as the town in which the fifty-fifth meeting of the Association should be held.

On Thursday an excursion was organised to Zell-am-See. On Saturday the third general meeting.was held. Prof. Oppolzer (Vienna) read a paper on the question: Is Newton's law of gravitation sufficient for the explanation of the motion of heavenly bodies? Are there reacons for regarding it only as approximately true? In consideration of the theories of the moon, of Mercury, and of Encke's comet, he cannot find the the rries based on Newton's law in its present form sufficient, but it would suffice under the (hypothetical) assumption of a cosmic matter surrounding the sun. After an address given by Dr. Kirschensteiner (Munich), on Theophrastus Bombastus Paracelsurs, the sitting was closed by Dr. Günthner. We give a list of the papers read in the sections of Natural Science.

Section II. Physics: Walter (Tarnowitz), on the molecular kinetic laws of specific heat and the heat of vaporisation of bodies in different states; Sacher (Salzburg), on a direct measure of the attraction between earth and a determined electric current; Kurz (Augsburg), on dispersion of light and measuring the index of refraction; Spörer (Potsdam), results obtained by observations of the sun; Grunmach (Berlin), on the electro-magnetic rotation of the plane of pularisation of radiant heat; Grunmach (Berlin), comparisons of mercurythermometers with air-thermometers; Sacher (Salzburg) demonstrated some new physical experiments relating to the theory of the formation of the earth (balls of sulphur and spermaceti with crater-formations) ; Waltenhofen (Prague) spoke on his apparatus for demonstration of the different action of hollow and solid electro-magnets; Guinther (Ansbach), on the parallelogram of forces.

Section III. Chemistry: Bribl (Lenberg), on the connection between the optic and thermic properties of liquid organic bodies ; Brauner (Prague), contributions to the chemistry of the rare earths, and on the progress of the system of periodicity of elements; Schwarz (Gratz), short communication on the preparation of nearly perfect alum.cubes by a new method; Zorn (Heidelbers), on hyponitrous acid; Bernthsen (Heidelberg), on the nomenclature of the proper derivates of carbonic acid, taking special notice of isomers.

Sections IV, and V. Geology, mineralogy, palæontology, geography: Bernath (Budapest), on the mineral waters of Hungary; Guimbel (Munich), on the geological structure of the Untersberg (near Salzburg); Hauer (Vienna) presented a new geological map of Montenegro (desi med by E. Tietze); Zittel (Munich), on Spongiæ as rock-forming materials, and on Plicatocrinu; ; Baltzer (Zurich), on curved strata; Neumager (Vienna), on fresh-water Conchylia from China; Alth (Krakau), on the Jurassic formation of Niczniow; Hauer (Vienna), on the Arlberg; Tschermak (Vienna), on the definition of species in mineralogy; Hoernes (Gratz), on earthquake; in general; Woehner (Vienna), on the earthquake of Agram; Richter (Salzburg), on observations made at the Obersalzbach glacier; Doelter (Gratz), on the Cape Verde Islands ; Duicker (Bückeburg) on the occurrence of petroleum in Northern Gernany.

Section VIII. Botany: Kraus (Triesdorf), communications on the sap-pressure of plants; De Bey (Azchan), rep rrt on five new and peculiar generd (Coniferæ) of the Aachen chalk-flora; Holzner (Weihenstephan), on agrostological theses; Hildebrand (Freiburg-im-Breisgau), some observation; on the flowering and the fruits of plants; Woronin (St. Petersburg), contribution to the knowledge of Ustila rineæ; $\operatorname{Kirchner}(\mathrm{H})$ henheim), on the longitudinal growth of plants.

Sections VIII, and IX. Zoology, comparative anatomy, entomology: Troschel (Bonn), classification of Gastropods; Fraisse (Leipsic), on cell-division and free nucleus-formation Weidersheim (Freiburg), on the genesis of Jacobson's organ; Grobben (Vienna), on the variation of generations of Doliolum.

\section{BIOLOGY AS AN ACADEMICAL STUDY'}

\section{I.}

T $\mathrm{T}$ is told of the late Dr. Norman Macleod that, on paying his first visit in his first parish, he was peremptorily desired to sit down and "go over the fundamentals." I feel that some such demand may, not unreasonably, be made of me to-night.

Five-and-twenty years ago one's position in this respect would have been a comparatively easy one, for then biolozy may be said to have had no "fundamentals" at all. In spite of the labours of Buffon, Erasmus Darwin, and Lamarck, the great bulk of naturalists at that time believed in the immutability of species; as a natural consequence botany and zojlogy remained mere "classificatory sciences," and the extraordinary facts of comparative anatomy, of embryonic development, of geographical distribution, of palæontology, were incapaple of rational explanation. Indeed, classification itself was nothing more than a logical expression of likenesses and unlikenesses, and was devoid of all real meaning.

But with the publication of the "Origin of Species," in .1859, a better day dawned for biolozy. The whole history of science has been a succession of attempts to bring group after group of natural phenomena within the scope of some natural law; and Charles Darwin's great service to science lies in the fact that, although not himself the discoverer of the doctrine of descent, he succeeded, by the immense array of well-arranged facts and sound generalisations contained in his ejoch-making book, in

${ }^{x}$ Inaugural Lecture delivered in th॰ University Library, May $2, \mathrm{r} 83_{1}$, by T. Jeffery Parker, B.Sc., Lond., Professor of Biology in the University of Otago. 